\title{
A Study on Developing of Asset Pricing Models
}

\author{
Reza Raei \\ Associate Professor, faculty of Management, University of Tehran, Tehran, Iran \\ Hamed Ahmadinia (corresponding author) \\ Lecturer at Department of Accounting, Faculty of Teachers Training, \\ Shahre Ray Branch, Islamic Azad University, Tehran, Iran \\ E-mail:hamed.ahmadinia@gmail.com
}

Amaneh Hasbaei

MBA-Finace, Faculty of Management, University of Tehran, Tehran, Iran

Received: May 29, $2011 \quad$ Accepted: June 14, $2011 \quad$ doi:10.5539/ibr.v4n4p139

\begin{abstract}
This study introduces the development and modifications of the widely used standard capital asset pricing model (CAPM). Many modifications are applied to the model's challenging financial variables such as: financial risk factors, liquidity risks, downside risks, risk of non expected events, and economic and operational risk factors. Efficiency of the model is increased when applying various challenging financial variables. As a result of the gradual CAPM developments, various new models will present better interpretations of market conditions in economic units and portfolio structure. Furthermore, this study will show the importance of applying the new models advantages and disadvantages for financial managers, financial analysts and investors.
\end{abstract}

Keywords: Capital Asset Pricing Models, Behavioral Theory, Portfolio Management

\section{Introduction}

One of the methods investors utilizes to identify the risks and return on their investment is Capital Asset Pricing Model (CAPM). The CAPM will be referred as the standard model throughout the study. William Sharpe introduced the model in 1960. The standard model examines the effect of systematic risk (beta coefficient) on the investment portfolio. The beta coefficient is calculated by regression analysis between return of a managed portfolio and a benchmark portfolio. Many investors and financial analysts were interested in applying this model. Consequently, it has been applied in many recent studies, including: (Iqbaland Brooks, 2006) Lahore Stock Exchange; (Galagedera,2006) Australia Stock Exchange; (Grandes, Panigo and Pasquini, 2006) Latin American Stock Exchange; (Qin and Poyry, 2007) Oslo Stock Exchange; (Gunnlaugsson, 2007) Iceland Stock Exchange; (Xu-song and Cheng-qi, 2008) Shanghai Stock Exchange; and (Rogers and Securato, 2009) São Paolo Stock Exchange.In the subsequent studies, researchers discovered data distributions are not always normal, and as a result made some modifications to the CAPM. The researchers came up with a new model, named Downside Capital Asset Pricing Model (D-CAPM). The following studies were applied to the D-CAPM: (Estrada, 2007) Madrid Stock Exchange; (Cheremushkin, 2009) Moscow Stock Exchange; and (Cwynar and Kazmierkiewicz, 2010) Polish Stock Market. In the next step of developing CAPM, researchers examined the effect of liquidity risk on the model. The result of this examination led the researches to the introduction of Adjusted Capital Asset Pricing Model (A-CAPM). Like previous models, this model used for evaluating the efficiency of portfolio management by (Pastor and Stambaugh, 2003), (Acharya and Pedersen, 2005) New York Stock Exchange; (Soltani, Eslamizadeh and Nooryan, 2010) Tehran Stock Exchange; and (Minovic and Zivkovic, 2010) Belgrade Stock Exchange.

Other factors of developing CAPM were estimating effects of changing macroeconomic, variables such as unexpected changes in inflation, employment opportunities and future stock market returns. Researchers introduced Inter-temporal Capital Asset Pricing Model (I-CAPM). Several studies have been done by using this model (Chang,Hung and Lee, 2003) Taiwan Stock Exchange; (Lo and Wang,2006) New York Stock Exchange; (Maio, 2008) Istanbul Stock Exchange; and (Bali and Engleb, 2009) New York Stock Exchange.

Changes in market conditions and non-homogenous expectations of investors from their investment portfolio performance led to another development in CAPM. This development created the Conditional Capital Asset Pricing (C-CAPM). This model attracted the attention of many researchers. The model was examined in several studies (Kumar et al., 2008) New York Stock Exchange; (Palandri, 2009) Copenhagen Stock Exchange; (Lee, Tsai, and Lee, 
2009), (Adrian and Franzoni, 2009) and (Guermat and Freeman, 2010) New York Stock Exchange. Another important development took place in CAPM when researchers were paying attention to the impact of financial, operational, combined and economic leverages in efficiency of portfolio management. In this regard, a comprehensive model considering the impact of these factors on portfolio management was developed. Therefore, the Revised Capital Asset Pricing Model (R-CAPM) was presented. This model was examined in the following studies: (Rahnamay Roodposhti, Nikomaram and Amirhosseini, 2009), (Amirhosseini, Rahnamay Roodposhti and Khosroyani, 2010) and, (Rahnamay Roodposhti and Amirhosseini, 2010) Tehran Stock Exchange.

One of the other factors playing a key role in applying CAPM is the total consumption cost in investment. The new model presented in this case is the Consumption Capital Asset Pricing Model (Co-CAPM). The efficiency of this model was examined by: (Garcia Renault and Semenov,2005) New York Stock Exchange; (Monnin, 2007) New York, Tokyo, London and Swiss Stock Exchanges; and (Panopoulou and Kalyvitis, 2007) Athens Stock Exchange.Recently, researchers have been interested in evaluating the impact of expected and unexpected return on the investment portfolio. In this respect, it should be noticed researchers have a long way for designing a comprehensive model. However, this model known as Reward Capital Asset Pricing Model (R-CAPM) studied by (Bornholt, 2006) New York Stock Exchange and (Rogers and Securato,2007) Sao Palo Stock Exchange.

The latest modification on CAPM is changing managers' perspective from financial factors to behavioral factors that have influence on portfolio performance. Even though, the process of this trend is obvious in all financial models. Behavioral Assets Pricing Model (B-P) is the result of these developments. This model with the aim of investor in acquisition portfolios, divides his investment portfolio into the different segments, including income, value, blend and growth. The following studies was conducted on the B-P model (Hirshleifer, 2001); (Statman, 2003); and (Adams, Mullins \& Thornton, 2007) in Norway.

In the following sections, we will present more detail and discuss the advantages and disadvantages of each model.

\section{Standard Capital Asset Pricing Model (CAPM):}

In 1950 Markowitz, introduced the modern portfolio theory and discussed the relationship between expected rate of return and risk. After that, William Sharpe introduced the standard capital asset pricing model (CAPM). According to William Sharpe aims and applications, some assumptions are associated with this model. However, before mentioning them, we must pay attention to utilization of this model as follows:

Determine a theoretically expected required rate of return of an asset and employing it for discounting securities

Analysis and illustration of capital structure

Determining the expected rate of return and evaluating effects of market risk factors and unit risk factors on the expected rate of return

The standard model assumes that market behavior is symmetrical. Thus the risk the investor takes should be proportional to the gains of expected returns of investment. As it shown in Figure 1:

The capital asset pricing model is a price regression model with the following equation:

$K_{j}=R_{f}+\beta\left(R_{m}-R_{f}\right)$

$\mathrm{Rf}=$ the risk-free rate of interest such as interest arising from government bonds

$\beta=$ the sensitivity of the expected excess asset returns to the expected excess market returns

$\mathrm{Rm}-\mathrm{Rf}=$ risk premium

The Beta $(\beta)$ is the most important factor in this model, because it identified and compared expected rate of return with the actual rate of return for a managed portfolio. Beta coefficient determined the sensitivity of the expected excess return of assets toward the market expected excess return. Based on Sharpe's model it can be obtained from the following equation:

$\beta=\frac{\operatorname{Cov}\left(r_{i}-r_{m}\right)}{\operatorname{Var}\left(r_{m}\right)}$

CAPM enables us to estimate investment risk and expected rate of return. The starting point of this model is the risk-free rate of return. Since investors expect a reward for their risk-taking, rewards are also added to the risk-free rate of return. This additional obtained reward that Sharpe named "beta" is equal with market risk premium. Beta is the unit of measurement for systematic risk of stock. Actually, the beta measures the sensitivity of stock return variance to market return variance. Black, Jensen and Scholes, in 1972 by empirical tests on the CAPM using the stock pricing procedure in companies listed in the New York Stock Exchange from 1931 to 1965 proved there is a liner relationship between stock portfolio return and its beta, supporting the above equation.

Criticism of the capital asset pricing model: 
From the early 1980's, the efficiency of CAPM has been criticized. For instance, (Reilly and Brown, 2000) raised questions about the stability of beta and the linear relationship between return and return rate of assets. Table 1 briefly mentioned some of these criticisms.

One of the most important studies done by (Fama and French, 1992) summarized the findings of previous empirical studies and relying on Fama-Macbeth cross-sectional regression method. Fama and French examined the relations among beta variables, contribution measures, and book value to market price ratio, financial leverage, and interest to the expected stock return price ratio in US capital market. The results indicated that systematic risk (beta) was not able to identify all the stock return variations during (1963-1990). Among variables they studied in their research only two variables, including company size and book value to the market price ratio can provide a better determination for the stock return average variance. According to Fama and French, firm size and book value to the market value ratio are related to the systematic pattern of growth and profitability. They are potentially major sources of risk in return. These two mentioned variables were known in most studies as two specific market indictors that raise questions about the model. These findings diminished the credence of this model, and a new wave was formed in the development field of financial theories with the aim of explaining the causes of these special consequences.

\section{Downside Capital Asset Pricing Model (D-CAPM):}

Researchers realized that in a situation in which return distributions is not normal, we encounter the risk of having lower return than expected return, which is logically employed in capital evaluation. Markowitz in 1959 defined semi-variance and standard deviation as appropriate criteria for choosing a portfolio. D-CAPM is the confirmed model than the CAPM in which return distributions of lower or higher than the symmetry border is taken into account. The framework of this model is introduced by (Hogan and Warren, 1974), (Bawa and Lindenberg, 1977) and (Harlow and Rao,1989). Later, Estrada modifies D-CAPM in 2002. Estrada identified that this model does not meet diversification purposes, and also it is not compatible with the portfolio theory. Additionally, he believed that in an asymmetric market, the capital asset pricing model and the downside asset pricing model could respectively provide $38 \%$ and $55 \%$ correct estimations of the expected rate of return. Although measuring semi-variance is completely useful and correct, but the formula introduced for calculating covariance contains some statistical errors. Thus, it cannot present the actual dependency between two assets. This measure does not present high return rates of one asset to cover reductive return rate of other assets, for a specific portfolio.

Simulations show that if the assets have positive and complete correlation with expected returns in the capital asset pricing model, then the probability of error is zero. Otherwise, if the assets have negative and complete correlation with expected returns in the capital asset pricing model, then the probability of error is unlimited. Finally, if the assets have zero correlations with expected returns in the capital asset pricing model, then the probability of error is completely important. Therefore, this algorithm does not present reliable estimations. Consequently, this situation is observing reduced beta for a criterion that has the error, and is unsuitable for diversifying a portfolio or determining its semi-variance (Cheremushkin, 2009). However, this model has validity to explain cross-sectional returns in low level performance and new markets (below normal return distribution).

The CAPM is based on some assumptions such as every investor receives returns in proportion to the level of risk he takes. This assumption shows that this model must be applied to a symmetric market. If the conditions of a market change and investors do not receive returns in proportion to the risk they take, the market risk premium becomes negative. Therefore, this is the reason for introducing the D-CAPM that is applicable in the asymmetric markets. In 1970 's, financial experts focused on the concept of negative risk. The first study in this field was conducted by Levy in 1974. After Levy others including Warren introduced a model similar to CAPM. In order to explain this model, we must refer to some financial assumptions: expected return of shareholders is obtained by adding up the share-out return to the increase in stock price; in a capital structure an economic enterprise existence of debt affects the risk level induced by shareholders; whereby, the shareholders are faced with the business risk only. Thus, expected return is equal to the risk-free rate of return, plus the business risk premium and the financial risk premium. This is shown in Figure 2:

Therefore, in order to calculate beta in this model the following formula will be used:

$\beta^{D}=\frac{\operatorname{Semi} \operatorname{Cov}\left(R_{i}, R_{m}\right)}{\operatorname{Semi}-\operatorname{Var}\left(R_{m}\right)}$

In this regard, Nikoomaram in 2010 compared the two widely used pricing models, CAPM and D-CAPM, in the automobile manufacturing industry to suggest a more suitable model that can be used to estimate the expected return rate in such industries. The comparison was made through defining four hypotheses each focusing on the risk premium correlation rate as an independent variable with the expected return in the two models, CAPM traditional beta and D-CAPM downside beta. The expected return rate of the two models and finally the deviation rate of the 
expected return from the predicted return in both models. Results of his study indicated the superiority of D-CAPM over CAPM to determine the expected return rate in automobile manufacturing companies.

\section{Adjusted Capital Asset Pricing Model (A-CAPM):}

Researchers such as (Amihud and Mendelson, 1989), (Pastor and Stambaugh, 2003) and (Acharya \& Pedersen, 2005) discussed the importance of the liquidity risk factor on CAPM. They adjusted the standard model of Sharpe with considering the impact of liquidity risk on it, and they predicted expected returns in this situation. This model considers securities liquidity risk and market liquidity risk. In A-CAPM, the beta is obtained from the following equation:

$\beta^{A}=\frac{\operatorname{Cov}\left[\left(r_{i}-c_{i}\right)\left(r_{m}-c_{m}\right)\right]}{\operatorname{Var}\left(r_{m}-C_{m}\right)}$

$c_{i}=$ Security liquidity Risk

$c_{m}=$ Market liquidity Risk

Security liquidity risk is obtained from the following equation:

$C_{m}=\sum\left(\frac{V_{i}}{r_{i}}\right)$

$V_{i}=$ Trading volume (number of shares traded)

$r_{i}=$ Desired share of trading days

on the market

And market liquidity risk is obtained from the following equation:

$C_{m}=\sum\left(\frac{r_{m}}{r_{m}}\right)$

$V_{m}=$ Total trading days on the market

$r_{m}=$ Total market turnover

Effect of Liquidity on Capital Asset Pricing Model

As we mentioned in standard CAPM, under the hypothesis of capital market efficiency, return of assets is associated with covariance between the return on asset levels for each asset and market. Market risk premium is determined as follows:

$E\left(r_{i}\right)=E\left(R_{f}\right)+\beta_{i}\left[E\left(r_{m}-R_{f}\right)\right]$

If $r_{i}$ and $r_{m}$ are equal then expected return of assets and expected return of market, the systematic risk is calculated as follows:

$\beta_{i}=\frac{\operatorname{Cov}\left(r_{i}, r_{M}\right)}{\sigma^{2}\left(r_{M}\right)}$

In this situation, there is a stable relationship between stocks return and market return even though we used net return instead of gross return in the formula (Acharya \& Pedersen, 2005). Thus the above equation can be rewritten as follows:

$E\left(r_{i}\right)=E\left(R_{f}+c_{i}\right)+\beta\left[E\left(r_{m}-C_{M}-R_{f}\right)\right]$

$c_{i}=$ Non-cash expenses desired assets

$c_{M}=$ Non-cash expenses in the market

In this situation, systematic risk is calculated as follows:

$\beta_{i}=\frac{\operatorname{Cov}\left(r_{i}-c_{i}, r_{M}-c_{M}\right)}{\sigma^{2}\left(r_{M}-c_{M}\right)}$

If we mixed these two equations together, the expected equation to be expressed is as follows:

$E\left(r_{i}\right)=E\left(R_{f}+c_{i}\right)+\lambda \operatorname{Cos}\left(r_{i}-c_{i}, r_{m}-c_{M}\right)$

In this equation, $(\lambda)$ is expected return against accepting the market risk and non-cash expenses as follows:

$\lambda=\frac{\left[E\left(r_{M}-c_{M}-R_{f}\right)\right]}{\sigma^{2}\left(r_{M}-c_{M}\right)}$

(Acharya \& Pedersen, 2005) identified that non-cash risks can be divided into three parts as follows: 
Covariance of liquidity in asset level and market level: It occurs as a consequence of increasing return due to lack of liquidity in market and desired assets. The reason for this problem can be identify as lack of sufficient ability in the market for cash bonds.

Covariance of asset returns and impact of non-liquidity at the market level: It is observed there is a negative relationship between the covariance return of securities and liquidity of market. This matter was studied by (Holmstrom and Tirole, 2000) and (Lustig, 2001).

Covariance of asset liquidity and market return: This effect is due to the investors having less tolerance for accepting a lower expected return for securities on the falling market. Therefore, while the market is currently going down, the investors' wealth is falling down and the ability to sell is identified as a valuable matter.

Hence, in a situation where the stock return is decreasing an investor is expecting a reduced return. One of the problems of using a modified model based on the liquidity is determining a suitable input data for this model. Typically, directly calculating the net return is impossible. Since, the net return depends on the term held investments and the current economic situation. Previous studies identified the gross return and liquidity costs as effective factors on the effect of liquidity of the return. As discussed in the above equations the market debt can be traced. In this situation, systematic risk is calculated as follows:

$\beta^{*}=\beta \frac{S}{S+D(1-t)}$

\section{Inter-temporal Capital Asset Pricing Model (I-CAPM):}

The alternative model, I-CAPM introduced by Merton, in 1973, is a linear factor model with wealth and status variables that forecasts changes in the distribution of returns and future income. Investors used this model for solving the long-term decisions while they were facing an uncertain situation. The main difference between standard CAPM and I-CAPM is misstating variables. In fact, investors tried to avoid the negative effects of these variables in situations of the bear and bull in the market. Merton said investors act based on current and upcoming market conditions to cover their risk. Therefore, when investors want to decide about their investments, they should consider variables such as inflation, employment opportunities and future stock market returns.

The I-CAPM could have many applications. (Chang, Hung and Lee, 2003) used this model for evaluating the ability of choosing optimal portfolio and assessment exist capabilities in the timing ability on an investment portfolio. The results of their study indicated based on careful planning and scheduling when was the best time to invest. Classifying for making their investment asset allocations has a positive ability on market timing. They can detect market opportunities at the right time and by using these opportunities make the maximum profit for their shareholders.

Paulo Maio in 2008 used this model to evaluate three factors, future cash flow perspective, equity and the prospects of the bonds future perspectives. His research results showed that the I-CAPM predicted better conditions of future investment portfolio than the Fama and French three factor model. Unlike, the Fama and French model, this model can estimate unusual trends facing the risk premium. In addition, recent studies have expressed remarkable results about I-CAPM. The impact of changing in risk and return in the New York Stock Exchange, according to the average of Dow Jones Industrial index was investigated by (Bali and Engle, 2009).

\section{Conditional Capital Asset Pricing Model (C-CAPM):}

The main difference between C-CAPM and standard CAPM is in variables such as possible changes and challenges in investment performance that investors consider valuable and important in some of their financial transactions for preventing bankruptcy. This model expressed that not all investors have similar expectations and the main reason for this matter is changing in market conditions. (Hansen and Richard, 1978) introduced C-CAPM as a general model for unconditional capital asset pricing model. C-CAPM assumed that all investors have the same conditional expectations for their assets return. In this case, we cannot use standard CAPM to predict the market conditions. This relationship is shown in figure 3 :

In this model beta is obtained from the following equation:

$\beta=\frac{\operatorname{Var}\left(r_{M}\right)}{\operatorname{Cov}\left(r_{i}, r_{M}\right)}$

The model is based on the following assumptions:

Investors always want to earn higher return than the risk involved in their investments.

Investors can change available stocks in their investment portfolio according to their expectations since these stocks don't need any diversifications. 
Capital asset pricing model is not without error.

(Filho, Garcia and Imoniana, 2009) tested the C-CAPM borrowing a leaf from (Jagannathan and Wang, 1996) using macroeconomics and financial variables from the Brazilian, German and Argentinean markets. Furthermore, their approach compared such results with the American figures. The results of their study indicated there is evidence that the C-CAPM of the North American market is perfectly applicable to the Brazilian, Argentinean and German markets (Jagannathan and Wang, 1996).

\section{Revised Capital Asset Pricing Model (R-CAPM):}

(Hawawini and Viallet, 1999) considered financial risk as the relationship between earning after taxes and earning before interest and taxes, and operational risk as the relation between EBIT and sales. The R-CAPM is composed of these components of risk for evaluating expected return of portfolio. The figure 4 is considered for better realizing these relations:

Assumptions considered in R-CAPM are operational, financial, and combined economic leverages. The relationship between these leverages is as follows:

Operational Leverage: Operational leverage is a measure of how revenue growth translates into growth in operating income. It is a measure of leverage and how risky (Volatile) is a company's operating income. Operating leverage presented relationships between changing operating income related to changes in net sales (Brigham and Eugene, 1995) as follows:

$D O L=\frac{\Delta E B I T}{\Delta Q}$

$\triangle E B I T=$ Earning before interest and tax

$$
\Delta Q=\text { Changes in sales volume }
$$

Financial Leverage: Financial leverage refers to the use of debt to acquire additional assets. Financial leverage is also known as trading on equity (Weston and Eugene, 1969) as follows:

$D F L=\frac{\triangle E P S}{\triangle E B I T}$

$\triangle E P S=$ Changes in earning per share $\quad \triangle E B I T=$ Earning before interest and tax

Combined Leverage: Combined leverage is the ratio that summarizes the combined effect of the degree of operating leverage and the degree of financial leverage on earnings per share (EPS) given a particular change in sales. This ratio can be used to help determine the most optimal level of financial and operating leverage to use in any firm (Brigham, 1995) as follows:

$$
\begin{aligned}
D C L & =\frac{\Delta E P S}{\Delta Q} \\
\triangle E P S & =\text { Changes in earning per share }
\end{aligned}
$$$$
\Delta Q=\text { Changes in sales volume }
$$

Economic Leverage: (Griffin and Dugan, 2003: 179-189) considered multiple dimensions of systematic risk defined by Hawawini and Viallet empirically represented the economic risk construction through the use of the term and degree of economic leverage (DEL). They define DEL as a percentage change in firm's sales resulting from a unit percentage change attributable to an exogenous disturbance, so:

$$
D O L=\frac{\Delta Q}{\Delta Z}
$$

$\Delta Q=$ Changes in sales volume $\Delta Z=$ Economic shocks or changes in economic variables

Finally, the revised asset pricing model is as follows:

$$
K_{j}=R_{f}+\beta^{R}\left(R_{m}-R_{f}\right)
$$

The beta coefficient is derived from the following formula:

$$
\beta^{R} \text { or } \beta_{i}=(D E l)(D F L)(D O L) \beta_{i}^{o}
$$

And beta-zero can be expressed as follows: 
$\beta_{j}^{o}=\frac{\operatorname{Cov}\left[\left(\frac{\pi_{j}, t-1}{Z_{j}, t-1}\right)\left(\frac{Z_{j}, t}{E_{j}, t-1}\right) \widehat{R}_{m}, t\right]}{\delta_{m}^{2}, t}$

Whereas,

$\pi_{j}, t-1=$ earnings after interest and taxes

$Z_{j}, t=$ next period financial cost

share

$\widehat{R}_{m}, t=$ next period market value

$$
\begin{aligned}
& Z_{j}, t-1=\text { current period financial cost } \\
& E_{j}, t-1=\text { current period market value or net worth of market } \\
& \delta_{m}^{2}, t=\text { next period market index variance }
\end{aligned}
$$

Therefore, R-CAPM used the total risk (systematic risk and non-systematic risk) for evaluation. The results of research by (Rahnamay Roodposhti, Nikomaram and Amirhosseini, 2009) and (Amirhosseini, Rahnamay Roodposhti and Khosroyani, 2010) in Tehran Stock Exchange showed that the R-CAPM has better performance for predicting and identifying expected return and risk for investment portfolio than standard CAPM. In one of the recent analyses done in connection with the performance of this model, (Rahnamay Roodposhti and Amirhosseini, 2010) tested efficiency of R-CAPM compared with Fama and French three factor model. The results of their study identified that the R-CAPM is more efficient than Fama and French model.

\section{Consumption Capital Asset Pricing Mode (Co-CAPM):}

Robert Lucas in 1978 and Douglas Breeden in 1979 Nobel Prize winners in economics are the founders of the consumption capital asset pricing model (Co-CAPM) between 1978 and 1979.The Co-CAPM is an extension of the standard CAPM. Co-CAPM is the best theoretical model, but it can help make sense in the variation of the financial asset returns over time. And in some cases, its results can be more credible than those achieved through the CAPM.

In the Co-CAPM, risky assets create uncertainty in an investor's wealth and consumption. What an investor spends is uncertain as a consequence of investment decision in a risky market. In the CAPM, the risk premium on the market portfolio measures the price of risk, while the beta states the quantity of risk. On the other hand, C-CAPM quantity market risk is measured by movement of the premium with consumption growth. Thus, the Co-CAPM explains how much the entire stock market changes related to the consumption growth. While the CAPM rarely is used empirically, it is highly relevant in theoretical terms. In fact, the Co-CAPM was not used as was the standard CAPM in the real world. Therefore, a firm assessing a project or the cost of capital is more likely to use the CAPM than the Co-CAPM. The major reason for this is that the Co-CAPM tends to perform poorly on empirical grounds. This may be because a proportion of the consumers does not actively take part in the stock market. Thereby, the basic link between consumption and stock returns assumed by the Co-CAPM cannot hold. For this reason, the Co-CAPM may perform better than the CAPM for people who hold stocks.

From an academic point of view, the Co-CAPM is more widely used than the CAPM. This is because it incorporates many forms of wealth beyond stock market wealth and provides a framework for understanding variation in financial asset returns over many time periods. This provides an extension of the CAPM, which only takes into account one period of asset returns. The Co-CAPM also provides a fundamental understanding of the relationship between wealth and consumption and an investor's risk aversion. A simple version of the Co-CAPM is a linear representation between a risky asset and the market risk premium. Even so, the diversity is the definition of the so-called implied risk-free rate, implied market return and the consumption beta. Consequently, the formula for Co-CAPM is as follows:

$\bar{r}_{a}=r_{f}+\beta_{C}\left(\bar{r}_{m}-r_{f}\right)$

In the above equation we have:

$r_{f}=$ risk-free rate

$$
\bar{r}_{a}=\text { expected returns on risky asset }
$$

$\bar{r}_{m}=$ expected market return

$\bar{r}_{m}-r_{f}=$ market risk premium

$\beta_{C}=$ consumption beta of the asset

The returns and risk premium are identified by the investors' consumption growth and the risk aversion. Furthermore, the risk premium defines the compensation that investors require for buying a risky asset. As in the standard CAPM, the model links the returns of a risky asset to its systematic risk. The systematic risk is provided by the consumption beta. The consumption beta is defined as: 
$\beta_{c}=\frac{\operatorname{Cov}\left(\bar{r}_{a}, \text { consumption.growth }\right)}{\operatorname{Cov}\left(\bar{r}_{m}, \text { consumption.growth }\right)}$

As it has been shown in Figure 5, higher consumption beta points to higher expected return on the risky asset.

Panopoulou and Kalyvitis in 2007 adopted a spectral approach to re-estimate the values of risk aversion over the frequency domain. Their findings indicate that a lower frequencies risk aversion falls substantially across countries; consequently, yielding in many cases reasonable values of the implied coefficient of risk aversion.

\section{Reward Capital Asset Pricing Mode (Reward-BETA):}

Graham Bornholt in 2006 said that investors need a better methodology to estimate the expected stock returns in the stock market. In this regard, he suggested the use of the reward beta model as an alternative model for capital asset pricing model. Assumptions of this model are consistent with the arbitrage theory. He divided returns of stock into two parts, as follows:

1 - Expected stocks returns

2 - Unexpected stock returns

Thus, the reward beta model is as below:

$E\left(r_{i}\right)=R_{F}+\beta\left[E\left(R_{M}\right)-R_{F}\right]+\beta \cdot r_{i}\left[R_{M}-E\left(R_{m}\right)\right]$

In this model, the reward beta of stock I, is calculated as follows:

$\beta_{r}=\frac{E\left(R_{i}\right)-R_{f}}{E\left(R_{m}\right)-R_{f}}$

In order to calculate reward beta for the predicting future return on stock, we should divide the average of the monthly stock risk premium of the previous period by the average of monthly market risk premium of the same period. The calculated beta is used for predicting return of stock for next period.

In the above equation,

$E\left(R_{i}\right)-R_{f}=$ market risk premium for the period $\mathrm{t}$

$E\left(R_{m}\right)-R_{f}=$ difference between expected return for the period $\mathrm{t}$ and expected return for market.

$\beta_{r}=$ reward beta

Bornholt ranked stocks available in New York Stock Exchange during 1963 to 2003 based on (Fama and French, 1992) methodology. The results of his study indicated that the reward beta is more efficient for predicting expected return of stocks than CAPM. (Rogers and Securato, 2007) repeated the study of Bornholt in The SaoPalo Stock Exchange from 1967 until 2006. They used similar methodology that Bornholt used. Results of their study also confirmed that the previous study shown superior performance for reward beta model than CAPM.

\section{Behavioral Asset Pricing (BAP):}

Nowadays, the behavior of a person in a transaction is quite important. This point introduced the basis of behavioral finance. Hirshleifer in 2001 expressed that behavioral asset pricing paradigm is under development in the literature of behavioral finance. In the future, with more attention given to this type of financial literature, the capital asset pricing model will be replaced with BAP theory. Behavioral theory is focused on the definition of the behavior of investors in selecting investment units. It can also be a basis for determining proper performance. In particular, according to this theory investors make their portfolio of securities a layered pyramid. Therefore, the lower parts of this pyramid are designed for protecting poverty in investment protection for inclement conditions. Furthermore, the upper parts of the pyramid are designed for the potential of a favorable situation. Some investors fill the highest levels of the pyramid with a small number of diversified stocks in an investment portfolio, while the other investors are randomly choosing stocks without careful consideration of the layered pyramid. Investors always try to find the optimal solution for protecting their investment portfolio against losses. In this situation, the behavioral theory of capital asset pricing is formed. One of the main features in behavioral theory is reviewing investor perspective about the layered pyramid, not as individual investments but as whole layered sections in the pyramid for asset allocations. Whereby, sections intended for specific purposes join together in a situation where policies about accepting risk behavior among different sectors is possible; in part, with the aim of protecting against adverse market conditions. Thereby, investors have been protected against bankruptcy.

In a simple model of behavioral theory, investors divided their capital into two main sections. One section enables part of their investment to be protected against adverse conditions and the other section enables gaining maximum profit in favorable conditions. According to behavioral theory, investors divide their capital based on their goals and 
aspirations of many investments into various sectors. For example, Phantom Company's investment pyramid for 2003 is shown in figure 6 :

Statman, Fisher and Anginer in 2008 said stocks are like houses, cars, watches and most other products exude affect, good or bad, beautiful or ugly and admired or despised. Effect plays a role in pricing models of houses, cars and watches; however, according to the standard financial theory effect plays no role in pricing of financial assets. They outlined a behavioral capital asset pricing model where expected returns are high when both objective risk and subjective risk is high. High subjective risk comes with negative effect. Investors prefer stocks with positive effect, and their preference boosts the prices of such stocks and depresses their returns. Moreover, Adam Szyszka in 2008 presented the Generalized Behavioral Model (GBM) that describes how asset prices may be influenced by various behavioral heuristics and how the prices may deviate from fundamental values due to investors' irrational behavior. The model distinguishes three behavioral variables that are linked to errors in understanding and transforming information signals, problems with representativeness, and unstable preferences. The ultimate scale of behavioral mispricing depends on a measure $A$ - the ability of the market for self-correction. The discussion on factors influencing each of the model's variables is presented and illustrated with examples. The model is capable of explaining a vast array of market anomalies, including market under and overreaction, continuations and reversals of stock returns (momentum \& contrarian strategies), high volatility puzzle, small size and book-to-market effects, calendar abnormities, and others. Concluding remarks include discussion on the model's advantages and limitations, as well as potential directions for future development and research.

\section{Summarization:}

Table 2 lists each capital asset pricing model, their researchers, challenging economical variables, and in the last column a brief summary note regarding each model presented in this paper. Each model was extensively discussed, evaluated, analyzed and criticized by financial critics throughout the paper. In addition, various models were examined by many reputable economist and experts in financial firms and researched by university professors from 1970 - 2010.

\section{Conclusion:}

Choosing a capital assets pricing model would be successful if we could forecast all variables that may have direct or indirect effect on our portfolio investment. We mentioned in this paper many different risks such as: downside risk, financial risk, liquidity risk, and inter-temporal risk. Any of these particular risks could be forecasted prior to an investment. The outcome of any capital assets pricing model would be risk free with maximum return.

It is vitally important that investors be aware of present financial market conditions before choosing an appropriate model. Recently, researchers are recommending the Behavioral Assets Pricing (BAP) model. Although, we should point out this model's theory is still in the developing stage.

To conclude, it is recommended mean while; since, the BAP model is currently in the developing theoretical stage. Investment analysts and investors should thoroughly study, analyze and examine all aspect of behavioral factors that exist and play a role in this model's theory before making investments.

\section{References}

Acharya,V.,Pedersen,L. (2005). Asset pricing with liquidity risk, Journal of Financial Economics, forthcoming.2(77):375-410. http://dx.doi.org/10.1016/S1386-4181(01)00024-6

Adams,Michael,Mullins,Terry,Thornton,Barry,(2007).Pedagogical Strategies For Incorporating Behavioral Finance Concepts In Investment Courses, Journal of College Teaching \& Learning, 4(3):21-32.

Adrian,Tobias,Franzoni,Francesco A.(2009).Learning about beta: Time-varying factor loadings, expected returns, and the conditional CAPM,Federal Reserve Bank of New York in its series Staff Reports with number 193.

Amihud Y. (2002).Illiquidity and stock returns: cross-section and time-series effects, Journal of Financial Markets, 5:31-56. http://dx.doi.org/10.1016/S1386-4181(01)00024-6

Amihud, Y,Mendelson, H.(1989). The Effects of Beta, Bid-Ask Spread, Residual Risk, and Size on Stock Returns, the Journal of Finance, 44(2):479-486. http://dx.doi.org/10.2307/2328600

Amirhosseini, Zahra, Rahnamay Roodposhti, Fraydoon, Khosroyani, Mostafa.(2010). A Comparison Between R-CAPM and FAMA and FRENCH'S Models in Predicting Tehran Stock Exchange, Academic and Business Research Institute, OC10004/06: 1-9.

Amirhosseini, Zahra, Roodposhti, Fraydoon, Nikomaram, Hashem,(2008) Managing A Firm's Systematic Risk through Sales Variability Minimization- A Test of Three Competing Techniques.

Bali, Turan, Engle,Robert F.(2009). Investigating ICAPM with Dynamic Conditional Correlations, New York University Stern School of Business, 44 West Fourth Street, Suite 9-62, New York, NY 10012 
Bali,Turan G.,Engleb,Robert F,(2007). Investigating ICAPM with Dynamic Conditional Correlations,NYU,Working Paper No. FIN-07-051.

10. Banz, R. W. (1981). The Relationship Between Return And Market Value Of Common Stocks, Journal Of Financial Economics, 9: 3-18. http://dx.doi.org/10.1016/0304-405X(81)90018-0

Basu,S.(1983). The Relationship Between Earnings Yield, Market Value, And Return For NYSE Common Stocks: Further Evidence. Journal Of Financial Economics, 12:129-156. http://dx.doi.org/10.1016/0304-405X(83)90031-4

Bawa, Vijay, and Eric Lindenberg (1977). Capital Market Equilibrium in a Mean-Lower Partial Moment Framework., Journal of Financial Economics, 5:189-200. http://dx.doi.org/10.1016/0304-405X(77)90017-4

Bhandari, L.C.(1988). Debt/Equity Ratio And Expected Common Stock Returns: Empirical Evidence. Journal Of Finance, 43: 507-528. http://dx.doi.org/10.2307/2328473

Black, Fischer, Michael C. Jensen and Myron Scholes. (1972). The Capital Asset Pricing Model: Some Empirical Tests, in Studies in the Theory of Capital Markets. Michael C. Jensen, ed. New York: Praeger: 79-121.

Bornholt,Graham,(2006). Extending the CAPM: the Reward Beta Approach, Accounting \& Finance,7(1):69-83.

Breeden,D,(1979). An Intertemporal Asset Pricing Model with Stochastic Consumption and Investment Opportunities, Journal of Financial Economics, 55(1):117-142.

Brigham, Eugene F. (1995). Fundamentals of Financial Management

Chan, L.K., Hamao, Y. \& Lakonishok, J. (1991). Fundamentals and Stock Returns in Japan, Journal of Finance, 46: 1739-1789. http://dx.doi.org/10.2307/2328571

Chang,Jow-ran,Hung, Mao-wei, Lee,Cheng-few.(2003).An Intertemporal CAPM Approach to Evaluate Mutual Fund Performance, Review of Quantitative Finance and Accounting, 20(4):415-433, DOI: 10.1023/A:1024076518110.

Cheremushkin, Sergei Vasilievich,(2009). Why D-CAPM is a big mistake? The incorrectness of the cosemivariance statistics, Chair of Public and Local Administration, Economic Department of the Mordovian State University, Russia.

Chopra,N.,J.,Lakonishok, and J. Ritter,(1992). Measuring Abnormal Performance: Do Stocks Overreact?, Journal of Financial Economics, 31: 235-268. http://dx.doi.org/10.1016/0304-405X(92)90005-I

Chyi Lin Lee, Jon Robinson and Richard Reed.(2006) An Exploration of the Relationship between Size and Risk in a Downside Risk Framework Applied to Malaysian Property Shares, Pacific Rim Real Estate Society (Press) Conference., 12th Pacific Rim Real Estate Society Conference 22-25.

Cwynar, Wiktor, Kazmierkiewicz, Piotr. (2010). Is D-CAPM superior to CAPM when assessing investment risk on the Polish stock market?, Working Paper Series,SSRN Id.1550684.

Dastgir M., Ahmadina H. and Daghani R. (2011). Fund managemant: performance evaluation analysis, tehran stock exchange publication, volume one, in pressing

Dechow, P. M. and I. D. Dichev. (2002). The quality of accruals and earnings: The role of accrual estimation errors, The Accounting Review, 77(Supplement):35-59. http://dx.doi.org/10.2308/accr.2002.77.s-1.35

Estrada, Javier. (2007). Mean-semivariance behavior: Downside risk and capital asset pricing, International Review of Economics Finance, 16(2):169-185, http://dx.doi.org/10.1016/j.iref. 2005.03.003

Estrada,J.(2002). Systematic Risk in Emerging Markets: The D-CAPM, Emerging Market Review, 3: 365-379. http://dx.doi.org/10.1016/S1566-0141(02)00042-0

Fama, Eugene F. and Kenneth R. French.(1992). The Cross-Section of Expected Stock Returns, Journal of Finance. 47(2): 427-65. http://dx.doi.org/10.2307/2329112

Filho, Elmo Tambosi, Garcia, Fabio Gallo, Imoniana, Joshua Onome. (2009). Empirical Test of Conditional Capm Using Expected Returns of Brazilian, Argentinean, German and United States of American Portfolio, Corporate Ownership \& Control, 7(2): 269-279.

Galagedera, Don U.A. (2006). An alternative perspective on the relationship between downside beta and CAPM beta, Emerging Markets Review, 8(1):4-19. http://dx.doi.org/10.1016/j.ememar.2006.09.010

Garcia, Rene, Renault, Eric, Semenov, Andrei. (2005). A Consumption CAPM with a Reference Level,Universite de Montreal,Working Paper 1 Jan-2005.

Grandes, Martin, Panigo, Demian, Pasquini, Ricardo. (2006). The Cost of Equity beyond CAPM: Evidence from Latin American Stocks (1986-2004), Center for Financial Stability, Working Paper No18.

Griffin, H. F. and Dugan, M. T. (2003), Systematic Risk and Revenue Volatility. Journal of Financial Research, 26: 179-189. doi: 10.1111/1475-6803.00053. http://dx.doi.org/10.1111/1475-6803.00053 
Guermat, Cherif, Freeman, Mark C. (2010). A net beta test of asset pricing models, International Review of Financial Analysis, 19(1):1-9. http://dx.doi.org/10.1016/j.irfa.2009.09.008

Gunnlaugsson,Stefán B.(2007). A Test of The Capm on The Iclandic Stock Market, Lex et Scientia, 14(1): 193-199.

Hansen, Lars P., Richard, Scott. (1987). The role of conditioning information in deducing testable restrictions implied by asset pricing models, Econometrica 50:1269-1286. http://dx.doi.org/10.2307/1911873

Harlow,Van,Rao,Ramesh.(1989). Asset Pricing in a Generalized Mean-Lower Partial Moment Framework: Theory and Evidence, Journal of Financial and Quantitative Analysis, 24: 285-311.

Hawawini, G.,Viallet,C.,(1999). Finance for Executives (South Western College,Cincinnati, OH)

Hirshleifer,D. (2001): Investor Psychology and Asset Pricing. The Journal of Finance, LVI (4):1533-1597. http://dx.doi.org/10.1111/0022-1082.00379

40. Hogan, William, and James Warren, (1972).Computation of the Efficient Boundary in the E-S Portfolio Selection Model. Journal of Financial and Quantitative Analysis, 7:1881-1896. http://dx.doi.org/10.2307/2329623

Hogan,William,Warren,James.(1974). Toward the Development of an Equilibrium Capital-Market Model Based on Semivariance, Journal of Financial and Quantitative Analysis, 9: 1-11. http://dx.doi.org/10.2307/2329964

Holmstrom, B., Tirole, J. (2000). LAPM: a liquidity-based asset pricing model, Journal of Finance, 56: 1837-1867. http://dx.doi.org/10.1111/0022-1082.00391

Iqbal,Javed, Brooks, Robert.(2006).Alternative beta risk estimators and asset pricing tests in emerging markets: The case of Pakistan, Journal of Multinational Financial Management, 17(1):75-93. http://dx.doi.org/10.1016/j.mulfin.2006.04.001

Kent D. Daniel, David Hirshleifer and Avanidhar Subrahmanyam (2001),'Overconfidence, Arbitrage, and Equilibrium Asset Pricing,', Journal of Finance, 56(3): 921-965. http://dx.doi.org/10.1111/0022-1082.00350

Kumar, Praveen, Sorescu, Sorin M., Boehme, Rodney D., Danielsen,Bartley R., (2008). Estimation Risk, Information, and the Conditional Capm: Theory and Evidence, Review of Financial Studies, 21(3): 1037-1075. http://dx.doi.org/10.1093/rfs/hhn016

Lee, Cheng-Few, Tsai, Chiung-Min, C. Lee, Alice, (2009). A dynamic Capm with supply effect: Theory and empirical results, The Quarterly Review of Economics and Finance, 49(3):811-828. http://dx.doi.org/10.1016/j.qref.2009.01.001

Levy, R.A. (1974). Beta Coefficients as Predictors of Returns, Financial Analysts Journal, January-February:61-69. http://dx.doi.org/10.2469/faj.v30.n1.61

Lewellen, Jonathan, Nagel, Stefan, (2006). The conditional Capm does not explain asset-pricing anomalies, Journal of Financial Economics, 82(2):289-314. http://dx.doi.org/10.1016/j.jfineco.2005.05.012

Lo, Andrew W, Wang, Jiang, (2006). Trading Volume: Implications of an Intertemporal Capital Asset Pricing Model, Journal of Finance, 61(6):2805-2840. http://dx.doi.org/10.1111/j.1540-6261.2006.01005.x

Lustig, H. (2001). The market price of aggregate risk and the wealth distribution, Unpublished working paper, Stanford University.

Maio, Paulo. (2008). Intertemporal CAPM with bond risk premia,Faculty of Business Administration, Bilkent University, Ankara 06800, Turkey, Working Paper 2008-03.

Mandelbrot, B., and Hudson, R. L. (2004). The (Mis) Behavior of Markets: A ractal View of Risk, Ruin, and Reward. London: Profile Books.

Marcato Gianluca. (2005) CAPM, liquidity and real estate performances,, CASS Business School (City University), Faculty of Finance, Real Estate Finance and Investment Group., working paper.

Merton, Robert C. (1973). Theory of Rational Option Pricing. Bell Journal of Economics and Management Science (The RAND Corporation), 4(1):141-183, http://dx.doi.org/10.2307/3003143

Minovic, Jelena Z.,Zivkovic, Boško R.,(2010). Open Issues in Testing Liquidity in Frontier Financial Markets: The Case of Serbia, Economic Annals, LV(185):33-62, http://dx.doi.org/10.2298/EKA1085033M

Monnin,Pierre. (2007).Fundamental Stock Price with Consumption CAPM and Money Illusion: An International Comparison, National Centre of Competence in Research Financial Valuation and Risk Management, Working Paper No. 394.

Myer F.C.N. and Webb J.R. (1994). Retail stocks, retail REITs and retail real estate, Journal of Real Estate Research, 9:65-84. 
Nikoomaram, Hashem. (2010). Comparative analysis of sensitivity coefficient using traditional beta of Capm and downside beta of D-Capm in automobile manufacturing companies, African Journal of Business Management, 4(15):3289-3295.

Ostermark,Ralf.(1993). Portfolio Efficiency of a Dynamic Capital Asset Pricing Model Empirical Evidence on Finnish and Swedish Stock Data, ikbo Akademi University, Department of Business Administration, Henriksgatan, Finland.

Palandri, Alessandro. (2009). The Effects of Interest Rate Movements on Assets' Conditional Second Moments, School of Economics and Management Aarhus University, Creates Research Paper 2009-32.

Panopoulou, Ekaterini, Kalyvitis, Sarantis. (2007). Measuring Risk Aversion across Countries from the Consumption-CAPM: A Spectral Approach, Department of Statistics and Insurance Science, University of Piraeus, Working Paper 2007.

Pastor, Lubos, Stambaugh, Robert F., (2003). Liquidity Risk and Expected Stock Returns, Journal of Political Economy, 111(3):642-684. http://dx.doi.org/10.1086/374184

Qin, Yan, Parry, Econ. Discount Rates for Energy Investments: A Capm-approach, Preliminary draft, This project is a research project headed by Econ Parry, in cooperation with ENOVA, Møreforsking, Statnett, Statoil Hydro, Senter for statlig økonomistyring (SSØ) and Resources for the Future (USA). It is part of the RENERGI (Clean Energy for the Future) Program funded by the Norwegian Research Council.

Qin, Yan, Pöyry, Econ. (2007). Discount Rates for Energy Investments A CAPM-approach, a research project headed by Econ Pöyry, in cooperation with ENOVA, Møreforsking, Statnett, StatoilHydro, Senter for statlig økonomistyring (SSØ) and Resources for the Future (USA). It is part of the RENERGI (Clean Energy For the Future) Program funded by the Norwegian Research Council:1-21.

Rahnamay Roodposhti, Fraydoon, Amirhosseini, Zahra. (2010). Revised capital assets pricing model: an improved model for forecasting risk and return. Journal of Finance and Accountancy,Id09355:1-9.

Rahnamay Roodposhti, Fraydoon, Nikomaram, Hashem, Amirhosseini, Zahra. (2009). Managing A Firm's Systematic Risk Through Sales Variability Minimization- A Test of Three Competing Techniques, Global Economy \& Finance Journal,2(2):63-74.

Reilly, F.K., Brown, K.C. (2000). Investment Analysis and Portfolio Management, 6th edition, The Dryden Press, Harcourt College Publishers, New York.

Rogers, Pablo, Securato, José Roberto. (2007). Reward Beta Approach: A Review, Dept. of Accounting, Finance and Economics, Griffith University, Working Paper, SSRN Id. 1019845.

Rogers, Pablo, Securato, José Roberto. (2009). Comparative Study on the Brazilian Market of the Capital Asset Pricing Model Capm Fama and French 3factors Model and Reward Beta Approach English, Associacao Nacional de Pos-Graduacao e Pesquisa em Administracao (ANPAD), 3(1): 159-179.

Roll, R. (1977). A Critique of the Asset Pricing Theory's Tests: Part I, Journal of Financial Economics, 4: 129-176.

Rosenberg, B., Reid, K., and Lanstein, R. (1985). Persuasive Evidence of Market Inefficiency, Journal of Portfolio Management, 11: 9-17. http://dx.doi.org/10.3905/jpm.1985.409007

Rossi,Eduardo,Santucci de Magistris,Paolo. (2009). A No Arbitrage Fractional Co integration Analysis of the Range Based Volatility, School of Economics and Management Aarhus University, Denmark.

Shanken, J. (1987).Multivariate proxies and asset-pricing relations: Living with the Roll critique, Journal of Financial Economics, 18: 91-110. http://dx.doi.org/10.1016/0304-405X(87)90062-6

Soltani, Ahmad-Khalife, Eslamizadeh, Omid, Nooryan, Saeid. (2010). Capital Asset Pricing Model \& Adjusted Capital Asset Pricing Model, Working Paper Series, SSRN Id.1577006.

Statman, Meir, Fisher, Kenneth L., Anginer, Deniz. (2008). Affect in a behavioral asset pricing model, Working Paper Series, SSRN Id.1094070

Statman,Meir. (2003).Behavioral Portfolios: Hope for Riches and Protection from Poverty,PRC WP 2003-9,Pension Research Council Working Paper:1-24.

Stattman, D.(1980). Book Values and Stock Returns. The Chicago MBA: A Journal of Selected Papers, 4: 25-45.

Szyszka,Adam. (2009). Generalized Behavioral Asset Pricing Model, IFCAI Journal of Behavioral Finance Hyderabad: ICFAI University Press,VI(1):7-25.:7-25.

Xu-song, XU, Cheng-qi, HOU. (2008). Capital Asset Pricing Model with Generalized Elliptical Distribution, Systems Engineering, Theory and Practice,28(1):17-23. 
Table 1. Criticism on the capital asset pricing model

\begin{tabular}{|c|c|c|}
\hline Researchers/Year & Studied Variable & Effect Mode \\
\hline $\begin{array}{l}\text { Fama and French (1992) } \\
\text { Dechow and Dichev } \\
(2002)\end{array}$ & Non-normal returns & Non-normal returns are considered as compensates for risk. \\
\hline $\begin{array}{l}\text { Chopra, Lakonishok and } \\
\text { Ritter (1992) }\end{array}$ & Differences in systematic risk & $\begin{array}{l}\text { They identified that differences in systematic risks ( } \beta \text { ) are not sufficient to } \\
\text { justify CAPM. }\end{array}$ \\
\hline $\begin{array}{l}\text { Chan, Hamao and } \\
\text { Lakonishok (1991) }\end{array}$ & Book value to market value & They realized that critiques of CAPM were not true. \\
\hline Banz (1981) & Size & $\begin{array}{l}\text { Average return of portfolio that is composed of small size company stocks, is } \\
\text { greater than Average return of portfolio that is composed of large size } \\
\text { company stocks. }\end{array}$ \\
\hline $\begin{array}{l}\text { Stattman (1980) } \\
\text { Rosenberg, Reid and } \\
\text { Lanstein (1985) }\end{array}$ & book value to market value ratio & $\begin{array}{l}\text { Average stock market returns in USA have a positive relationship with the } \\
\text { book value to the market value ratio. }\end{array}$ \\
\hline $\begin{array}{c}\text { Ball }(1978) \\
\text { Basu }(1977,1983) \\
\end{array}$ & Profit on Price ratio & $\begin{array}{l}\text { It is expected that stock will have a higher profit on price ratio, creating more } \\
\text { expected return. }\end{array}$ \\
\hline Bhandari (1988) & Financial Leverage & $\begin{array}{c}\text { There is a positive relation between average stock returns and financial } \\
\text { leverage. }\end{array}$ \\
\hline Shanken (1987) & $\begin{array}{l}\text { Evaluating efficiency of market } \\
\text { in curves of minimal variance }\end{array}$ & $\begin{array}{l}\text { Based on the sub-sets test that they have the minimum variance and } \\
\text { correlation coefficients between yields. }\end{array}$ \\
\hline \multirow[b]{2}{*}{ Roll (1977) } & \multirow[b]{2}{*}{$\begin{array}{l}\text { Critique empirical test of the } \\
\text { capital Asset Pricing models }\end{array}$} & He showed that there is a serious doubt in regard to CAPM. \\
\hline & & $\begin{array}{l}\text { CAPM tests are under a direction, and little evidence has confirmed the } \\
\text { efficiency of CAPM. }\end{array}$ \\
\hline
\end{tabular}

Table 2. Summarizes the discussions presented in this article

\begin{tabular}{|c|c|c|c|}
\hline $\begin{array}{l}\text { Model / } \\
\text { Theory }\end{array}$ & Researchers & Variables & Note \\
\hline $\begin{array}{l}\text { Standard } \\
\text { CAPM }\end{array}$ & William Sharp(1969) & $\begin{array}{c}\text { Beta, Risk-free Rate of Return, Risk, } \\
\text { Market Return }\end{array}$ & $\begin{array}{l}\text { This model is based on } 10 \text { hypotheses which } \\
\text { emphasis on symmetric market and the existence } \\
\text { of information in market. }\end{array}$ \\
\hline D-CAPM & $\begin{array}{l}\text { Haugen \& Warren(1974), Bawa } \\
\text { \&Lindenberg (1977), Harlow } \\
\text { \&Rao(1989), Strada(2002) } \\
\text { Nikoomaram (2010) } \\
\end{array}$ & $\begin{array}{l}\text { Semi-variance criterion and Beta in an } \\
\text { undesirable situation which is based on } \\
\text { semi-variance }\end{array}$ & $\begin{array}{l}\text { This model can be used when the distribution of } \\
\text { return is lower or upper than the symmetric level }\end{array}$ \\
\hline A-CAPM & $\begin{array}{c}\text { Amihud \& Mendelson (1989), Pastor } \\
\text { \& Stambaugh (2003). Acharya \& } \\
\text { Pedersen ( 2005) }\end{array}$ & $\begin{array}{l}\text { Liquidity risk in estimating investors' } \\
\text { Beta }\end{array}$ & $\begin{array}{l}\text { Liquidity risk of securities and liquidity risk of } \\
\text { return are considered in this model }\end{array}$ \\
\hline C-CAPM & $\begin{array}{l}\text { Hansen \& Richard (1987) } \\
\text { Filho, Garcia and Imoniana (2009) }\end{array}$ & $\begin{array}{l}\text { Beta is explained based on the division } \\
\text { of market variance by share and market } \\
\text { return covariance }\end{array}$ & $\begin{array}{c}\text { This model expresses that investors don't share the } \\
\text { same expectations because of the changes in } \\
\text { market situation }\end{array}$ \\
\hline R-CAPM & $\begin{array}{l}\text { Hawawini \& Viallet (1999) } \\
\text { Roodposhti, Nikomaram \& } \\
\text { Amirhosseini (2009) } \\
\text { Amirhosseini,Roodposhti and } \\
\text { Khosroyani, (2010) } \\
\end{array}$ & $\begin{array}{c}\text { Estimation of Beta of the revised model } \\
\text { of capital assets which is related to } \\
\text { operational Financial and economical } \\
\text { leverage, }\end{array}$ & $\begin{array}{l}\text { Attention is paid to financial, operational and } \\
\text { economical risk }\end{array}$ \\
\hline Co-CAPM & $\begin{array}{c}\text { Iqbal and Brooks ,(2006) } \\
\text { Panopoulou and Kalyvitis (2007) }\end{array}$ & $\begin{array}{l}\text { Beta is explained based on the growth in } \\
\text { inventors' consumption and growing } \\
\text { consumption in market }\end{array}$ & $\begin{array}{l}\text { The extensive amount of consumption Beta shows } \\
\text { the increased amount of return in risky assets }\end{array}$ \\
\hline Reward-BETA & $\begin{array}{c}\text { Galagedera (2006). } \\
\text { Rogers and Securato (2009) }\end{array}$ & $\begin{array}{l}\text { Return is divided to two parts: expected } \\
\text { and unexpected return of shares }\end{array}$ & $\begin{array}{l}\text { For estimating return Beta, mean of monthly beta } \\
\text { of the share in the last period is divided by mean of } \\
\text { Beta of market in the current period and this return } \\
\text { Beta is used for forecasting the return of the share } \\
\text { in the next period }\end{array}$ \\
\hline BPT & $\begin{array}{l}\text { Hirshleifer, (2001) } \\
\text { Statman, Fisher and Anginer (2008) } \\
\text { Adam Szyszka (2008) }\end{array}$ & $\begin{array}{c}\text { Explaining the behavior of investors in } \\
\text { choosing investing units is emphasized. } \\
\text { Moreover, it can be considered as a } \\
\text { basis for detecting a suitable } \\
\text { performance. }\end{array}$ & $\begin{array}{l}\text { Investors form their basket of securities as layers } \\
\text { in a pyramid }\end{array}$ \\
\hline
\end{tabular}




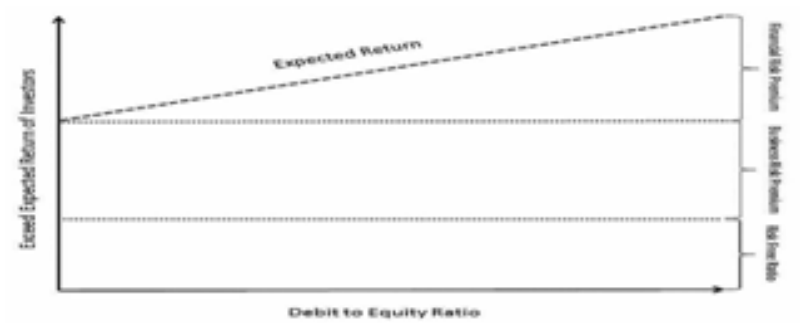

Figure 1. Exceed Expected Return of Investors and Debit To Equity Ratio

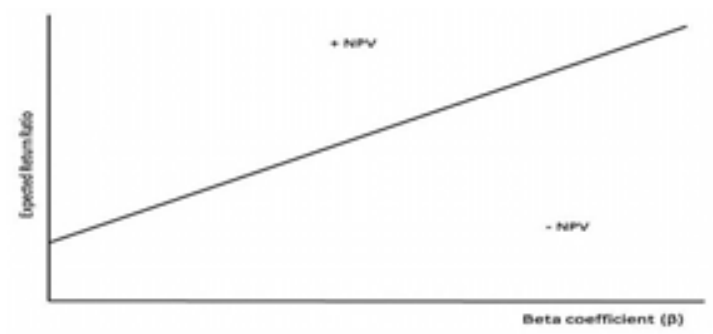

Figure 2.The Relationship between Beta and Expected Return Rate

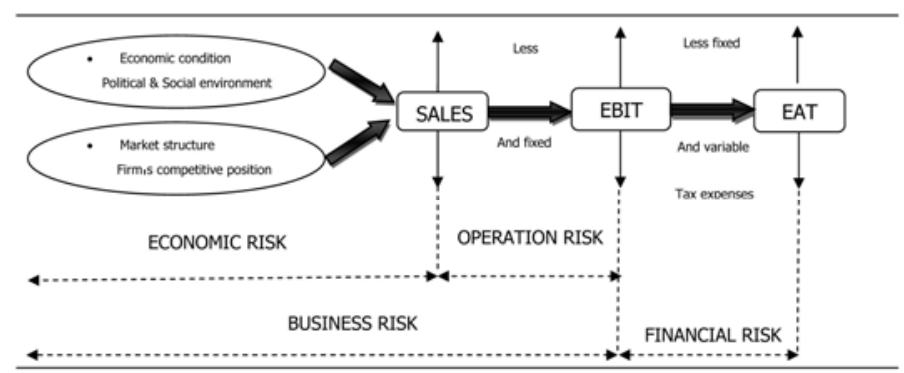

Figure 3.This figure shows the economic, operational and financial risk (Finance for Executives (1st ed.), by Hawawini and Viallet,1999)

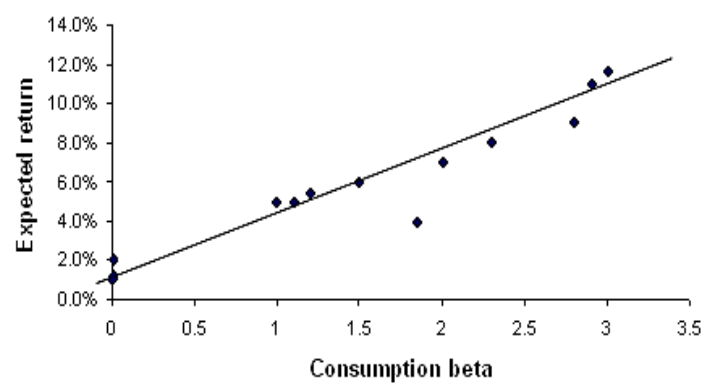

Figure 4. Expected return and consumption beta (Copyright Investopedia, 2006)

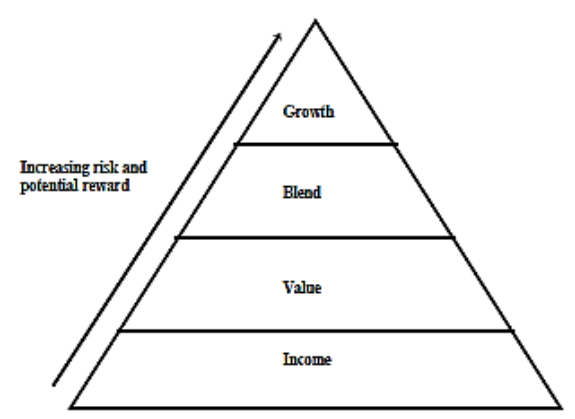

Figure 5. Portfolios as Layered Pyramids (Source: Putnam Investments, 2003) 